\title{
Leg Muscle Strength, Eye-Foot Coordination and Balance Associated With Soccer Shooting Skill
}

\author{
M. Ridwan ${ }^{1 *}$ and Ded Putra ${ }^{2}$ \\ ${ }^{1,2}$ Dep. of Coaching,Faculty of Sport Science, Universitas Negeri Padang, Indonesia \\ *Corresponding author. Email: m.ridwan@fik.unp.ac.id
}

\begin{abstract}
The problem in this study is the lack of ability to shoot soccer players in the Cendana Vocational School in Padang Panjang. The purpose of this study was to determine the relationship between leg muscle strength, eye-foot coordination, and balance to soccer shooting abilities. This type of research is correlational. The population in this study were 18 soccer players. The sampling technique used a total sampling of 18 people. The research instruments were leg muscle strength with a dynamometer leg, eye-foot coordination by kicking the target wall ball, balance with the stork stand, Shooting skill by kicking the ball into the ball by grading a scoring plot. Data analysis with productmoment correlation and multiple correlation. The results of the study are that there is a significant relationship between leg muscle strength and soccer Shooting skill, there is a significant relationship between eye-foot coordination and soccer Shooting skill, there is a significant relationship between balance and soccer Shooting skill, there is a significant relationship between leg muscle strength, eye-foot coordination and balance together towards the Shooting skill of the soccer player of Cendana Vocational School in Padang Panjang.
\end{abstract}

\section{Keywords: Leg Muscle Strength, Eye-Foot Coordination, Balance, Shooting Skill}

\section{INTRODUCTION}

Soccer is a game that is done by kicking the ball, with the aim to put the ball into the opponent's goal and defend the goal so as not to enter the ball. To be able to play soccer well, players must master the basic techniques of soccer and are supported by good physical conditions. Players who have good technique and good physical condition then these players tend to be able to play soccer well too. This is in line with the opinion of Sajoto quoted by Haryoko (20017) saying that: "Good physical ability to support soccer playing skills". One of the most important technical skills in soccer is the technique of kicking the ball into the goal or better known as shooting.

Many sports activities are supporting factors that influence to get achievements, such as physical condition, technique, tactics, and mentality (Soniawan, 2018). In soccer, besides having good physical, technical, tactic, and mental conditions, good technical mastery is needed for the athlete, because without good technical mastery, an athlete cannot realize his achievements.

According to Syukur \& Soniawan (2015), soccer is a game that requires a lot of energy, intelligence on the field stimulates enthusiasm while providing excitement through togetherness in a team. In soccer, there are various basic techniques for playing soccer. Basic techniques are fundamentals that must be mastered by all athletes in order to be able to play soccer skillfully based on multilateral movement skills.

Shooting is one of the basic techniques of playing soccer. Shooting is an attempt to move the ball from one place to another by using the foot or part of the foot. According to FIFA quoted by Anggi (2017) "Shooting is an action with the aim of putting the ball into the opponent's goal". This requires a player to have good shooting skills because shooting is the culmination of an attack that is the core of the game of soccer. Thus to be able to shoot well many factors that affect it include physical conditions including, leg muscle strength, eye-foot coordination, balance, flexibility, leg muscle burst power and the imposition of balls on the feet.

Cendana Vocational School in Padang Panjang City is one of the Schools that has conducted soccer sports coaching, which is carried out in soccer extracurricular activities aimed at developing students' talents in soccer so that later they are expected to develop talent and ask for and be able to excel. This soccer practice is held three times a week. From the results of observations made by the author on the field during practice and games on February 16, 2019, when players shoot when the ball moves, the shooting ball is often not on target, so the ball falls on an unwanted target, such as high on the goal, sometimes straying to the left and right sides of the goal, as well as when shooting immovable balls, such as shooting freekick, 
goal kick, and penalty, shooting is also not entered into the opponent's goal. Shooting is not hard and strong so it is easy to catch the goalkeeper. From the results of a survey between the Cendana Vocational School and the Padang Panjang 1 High School on March 15, 2019, the author sees the results of many players' shots being inaccurate.

Based on this, it is suspected that the lack of Shooting skill carried out by the soccer players of Cendana Vocational School in Padang Panjang is caused by 1) leg muscle strength, 2) ankle coordination and 3) poor balance. Leg muscle strength is crucial in shooting because in soccer a lot of kicks are done, both long-range and even towards the goal so that the player is able to make hard and strong kicks for a long time. In soccer, the ability of ankle coordination occurs when regulating the active role of the foot and eye in performing a series of technical movements.

In soccer, especially when shooting, coordination that plays a very important role is eye-foot coordination. Because without eye-foot coordination which is certainly difficult to do accurate shooting at goal, because the ball is kicked is not directed to the desired target. Body balance has an important role when shooting in soccer games. Balance is a physical element that is needed in all sports. Because, during fast movements, with changes in the location of weight points that are fast too, both static and dynamic. When shooting in a running condition the body is not balanced because it is done with one foot and holds all the limbs of the body so it is necessary to have a maximum body balance so that shooting is done right on the desired target.

Based on the description above, the researchers are interested in conducting research to obtain actual data and information about the relationship of leg muscle strength, eye-foot coordination, and balance to the Shooting skill of the Cendana Vocational High School soccer player in Padang Panjang City. According to Luxbacher (2011) "Shooting is a movement with one foot so the ball can move at a certain speed and reach the desired target". Shooting skill is one of the most important elements for winning in soccer because the main aim of shooting is to put the ball into the opponent's goal. In soccer, scoring is the most difficult task for a player to do. According to Bafirman (2012) "strength is the ability of a muscle to work with maximum load." Leg muscle strength is of course very decisive in shooting, because in soccer so often do shooting so that players are able to do hard and strong shooting in long game time.

According to Sukadiyanto (2011) said: "coordination is a combination of the movements of two or more joints, which are interrelated in producing one movement skill". In soccer, especially when shooting, coordination that plays a very important role is eye-foot coordination. According to Apri (2013) "Balance is a person's ability to control the nerves of the muscles so that they can control movements properly and correctly". Balance in the game of soccer is needed in the implementation of movements that take place quickly, for example, shooting in a running condition. Without balance, of course, players have difficulty in shooting accurately.

\section{RESEARCH METHODS}

This type of research is correlational. The population in this study were all soccer players of Cendana Vocational School in Padang Panjang City, totaling 18 players. The sampling technique uses total sampling. Thus the sample in this study amounted to 18 players. Data collection techniques are: 1) Leg muscle strength is tested with a dynamometer leg, 2) Coordination of the ankles is tested by kicking the target wall, 3) Balance is tested with a stork stand, 4) Shooting skill is tested by kicking the ball into the ball with the grading of the assessment plot. Data were analyzed with product-moment correlation and multiple correlation with a significant level $\alpha=0.05$.

\section{RESULTS AND DISCUSSION \\ 1. Leg Muscle Strength}

Of the 18 players, none of the players had leg muscle strength very good, good and moderate, 18 people $(100 \%)$ players had leg muscle strength with less classification and none of the players had leg muscle strength with very poor classification. For more, he explained the histogram of the player's leg muscle strength can be seen in picture 1 . 


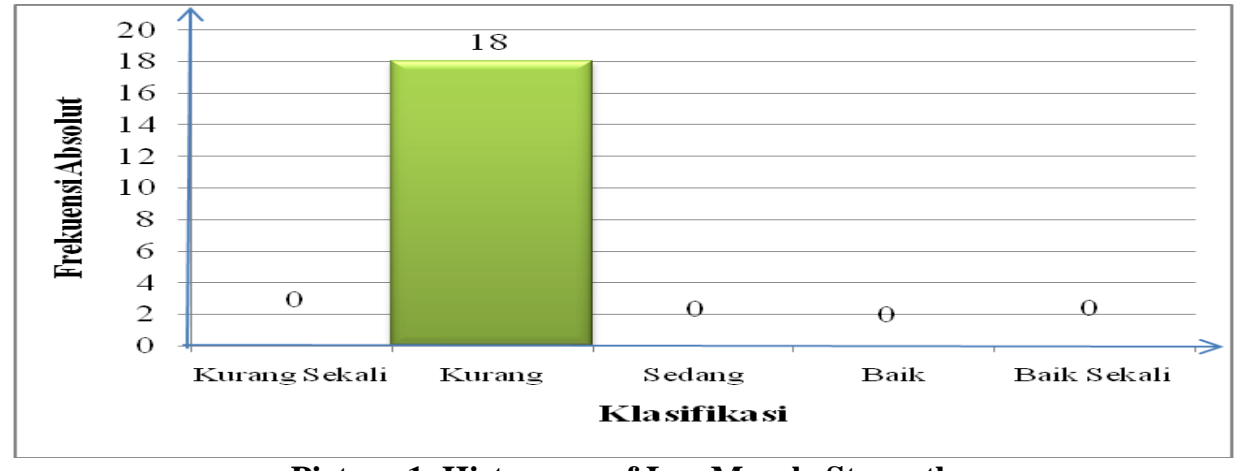

Picture 1. Histogram of Leg Muscle Strength

\section{Eye-Foot Coordination}

Of the 18 players who did not have good eyefoot coordination, 7 people $(38.89 \%)$ had good foot-eye coordination, $9(50 \%)$ had medium-level eyecoordination, 2 people $(11.11 \%)$ players who had eye- foot coordination with poor classification and none of the players who had eye-foot coordination with classification was very poor. For more details, the histogram variable of the player's eye-foot coordination can be seen in picture 2 .



Picture 2. Histogram of Eye-Foot Coordination

\section{Balance}

Of the 18 players, there are no players who have a balance with very good classification, good and moderate, 18 people (100\%) players have a poor classification balance and no player has a very poor classification balance. For more details can be seen in picture 3.

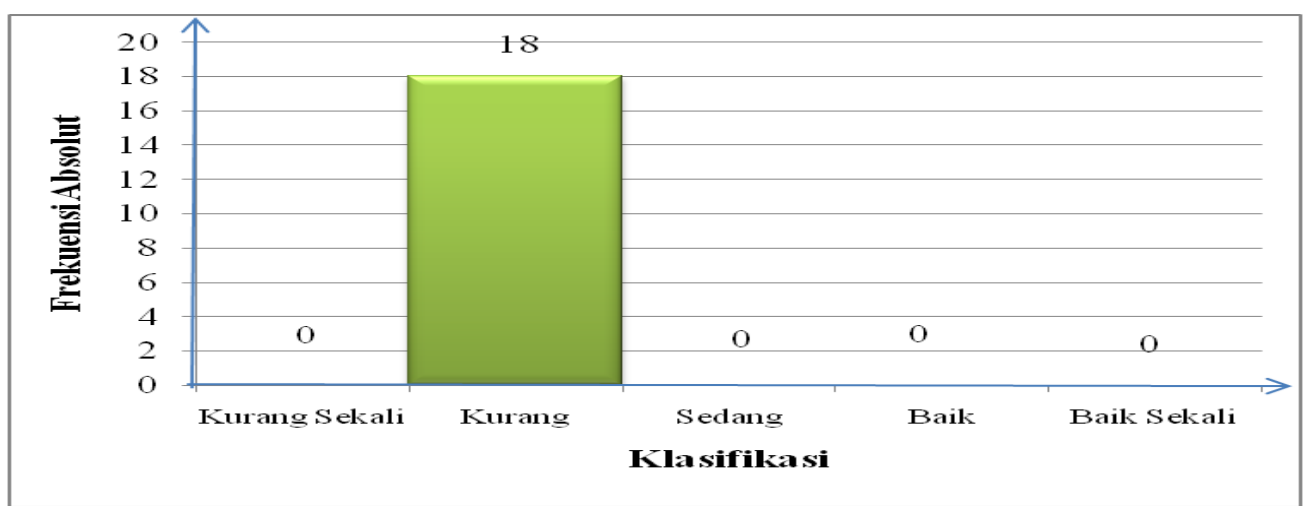

Picture 3. Histogram of Balance 


\section{Shooting Skills}

Of the 18 players in which, the ability to shoot with a very good classification is absent, 8 people $(44.44 \%)$ players have the ability to shoot with good classification, 6 people $(33.33 \%)$ players have the ability to shoot with medium classification, 4 people $(22,22 \%)$ players have poor classification shooting abilities and no players have very low classification shooting abilities. For more details on the variable histogram, shooting capability can be seen in Picture 4 .

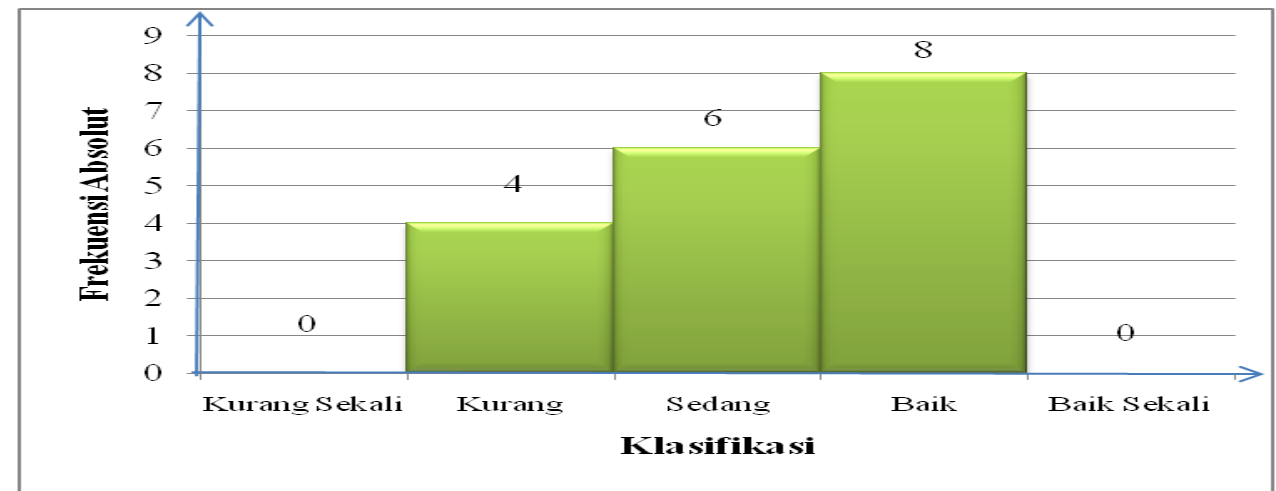

Picture 4. Histogram of Shooting Skills

Discussion

1. There Is A Significant Relationship Between Leg Muscle Strength And The Shooting skill Of Cendana Vocational High School Soccer Players In Padang Panjang City

Based on the results of the analysis of the correlation between leg muscle strength and Shooting skill, counts $0.553>$ table 0.468 and $\mathrm{t}$ arithmetic $=$ $2.655>\mathrm{t}$ table 1.746 with. Thus it can be concluded that there is a significant (significant) relationship between leg muscle strength and the Shooting skill of the Cendana Vocational High School soccer player in Padang Panjang City.

Thus, it is clear that the leg muscle strength affects the Shooting skill of the Cendana Vocational School soccer player in Padang Panjang City. Strength is the basic ability of physical condition. Strength is the power or pressure of a muscle, more precisely is a group of muscles that can be used against resistance from the maximum effort or effort. According to Ismaryati (2006) "Strength is the strength of muscle contraction that is achieved in a maximum effort. This maximum effort is made by a muscle or group of muscles to overcome a prisoner.

From the explanation above, it can be argued that leg muscle strength is an important factor that can affect the Shooting skill of Cendana Vocational High School soccer players in Padang Panjang City. Therefore, it is important to pay attention to the soccer coach of Cendana City of Padang Panjang Vocational School to be able to increase the strength of the players' leg muscles, including providing a form of leg muscle strength training, such as lifting, pushing or pulling a load.
2. There Is A Significant Relationship Between EyeFoot Coordination On The Shooting skill Of Cendana Vocational High School Soccer Players In Padang Panjang City

The results of the correlation analysis between eye-foot coordination on Shooting skill were obtained count of $0.532>$ table of 0.468 , meaning that there was a relationship between eye-foot coordination to the Shooting skill of soccer players at Cendana Vocational School in Padang Panjang. Based on the results of the ttest analysis, it turns out $\mathrm{t}$ arithmetic $=2.506>\mathrm{t}$ table with 1.729. Thus it can be concluded that there is a significant (significant) relationship between eye-foot coordination and the Shooting skill of the soccer player at Cendana Vocational School in Padang Panjang, empirically accepted the truth

According to Sukadiyanto (2011) said: "coordination is a combination of movements of two or more joints, which are interrelated in producing one movement skill". In soccer, especially when shooting at goal, coordination that plays a very important role is eye-foot coordination. Because without eye-foot coordination which is certainly difficult to shoot into the goal accurately. The eye functions to see the target and the foot as a medium for kicking so that it can get good accuracy.

From the explanation above, it can be stated that eye-foot coordination is an important factor that can affect the Shooting skill of the Cendana Vocational High School soccer player in Padang Panjang City. Therefore, it is important to pay attention to the soccer coach of Cendana Vocational School in Padang Panjang to be able to improve the player's eye-eye coordination, 
including providing a form of eye-coordination training, such as the practice of kicking the ball into the target with the feet, the practice of kicking the ball in pairs.

3. There Is A Significant Relationship Between The Balance Of The Shooting skill of Cendana Vocational School Soccer Players In Padang Panjang City

The results of the correlation analysis between the balance of Shooting skill is obtained a count of 0.524> table of 0.468, meaning that there is a relationship between the balance of the Shooting skill of soccer players in Cendana City of Padang Panjang. Based on the results of the t-test analysis, it turns out $t$ arithmetic $=2.471>\mathrm{t}$ table 1.729 with. Thus it can be concluded that there is a meaningful (significant) relationship between the balance of the Shooting skill of the Cendana Vocational School soccer player in Padang Panjang

According to Apri Agus (2013) "Balance is the ability of a person to control the nerve organs of the muscles so that they can control movements properly and correctly". When shooting in a running condition the body is not balanced because it is done with one foot and holds all the limbs of the body so it is necessary to have a maximum body balance so that shooting is done right on the desired target. Without having a balance, soccer players will not be able to shoot well and accurately, so balance is a component that needs to be owned by a soccer player. In addition, the balance will be able to increase strength and endurance, and also can easily control the position of the body when making a kick and also after doing a kick. Like kicking long distance and close range.

Based on the research results above, it is clear that the balance is significantly related to the Shooting skill. Therefore it is necessary to pay attention to the soccer coach of Cendana Vocational School in Padang Panjang to be able to improve the balance of the players, including providing forms of exercise that can improve body balance such as static progress and dynamic balance.

4. There Is A Significant Relationship Between Leg Muscle Strength, Eye-Foot Coordination And Balance Together To The Shooting Skill Of The Cendana Vocational High School Soccer Player In Padang Panjang City

The fourth hypothesis testing is done using multiple correlations. Based on the results of the calculation of multiple correlations obtained $\mathrm{r}$ count $=$ $0.691>\mathrm{r}$ table 0.468 , and $\mathrm{F}$ count $=4.264>\mathrm{F}$ table 3.34. This means that there is a significant relationship between leg muscle strength, eye-foot coordination and balance together to the shooting ability of the Padang Cendana Vocational High School soccer player.
According to Zalfendi (2010) "Kicking a ball (shooting) is an attempt to move the ball from one place to another by using the foot or part of the foot. Shooting is a basic technique of playing soccer that is most widely used in soccer games. The aim of shooting is to put the ball in the opponent's goal. According to Konger (2007: 39) "The skill to put the ball in the goal is very important to score. If a player cannot shoot the ball right into the goal, they cannot win the match ".

Thus, shooting is one of the most important elements to win in soccer, because the main purpose of shooting is to put the ball into the opponent's goal. In soccer, scoring is the most difficult task for a player to do. To score against an opponent, someone must have good shooting skills. The skill to score the ball into the goal is very important to score. If a player cannot shoot the ball correctly on goal, they cannot win the match.

From the results of the study, it is clear that the leg muscle strength, eye-foot coordination, and balance have a significant relationship to the shooting ability of the PadangCendana City Vocational High School soccer player. Leg muscle strength is very decisive in shooting, because in soccer very often do kicks, both long-range kicks and kicks towards the goal, so that players are able to shoot hard in a long time of course supported by good leg muscle strength.

Based on the results of the study, it is clear that leg muscle strength, eye-foot coordination, and balance have a significant relationship to the shooting ability of the Padang Cendana Vocational High School soccer player. These three factors should be trained and considered by the soccer coach of Cendana Vocational School in Padang Panjang.

\section{CONCLUSIONS AND SUGGESTIONS}

\section{A. Conclusions}

Based on the results of the study can be concluded as follows:

1. There is a significant relationship between leg muscle strength and the shooting ability of Cendana Vocational High School soccer players in Padang Panjang City.

2 . There is a significant relationship between eye-foot coordination on the shooting ability of Cendana Vocational High School soccer players in Padang Panjang City.

3. There is a significant relationship between the balance of the shooting ability of Cendana Vocational School soccer players in Padang Panjang City4. There is a significant relationship between leg muscle strength, eye-foot coordination and balance together to the shooting ability of the Cendana Vocational High School soccer player in Padang Panjang City. 


\section{REFERENCES}

[1] Apri, Agus. 2013. Olahraga Kebugaran Jasmani. Padang : Sukabina Press

[2] Anggi, Hidayatullah. 2017. Hubungan Kekuatan Otot Tungkai dan Koordinasi Mata-Kaki dengan Akurasi Shooting Pemain Sekolah Sepakbola Balai Baru Padang. Jurnal. Padang : FKIP Universitas Bung Hatta

[3] Bafirman, Apri Agus. 2012. Pembentukan Kondisi Fisik. Padang : Universitas Negeri Padang.

[4] Haryoko. 2017. Hubungan Kekuatan Otot Tungkai, Panjang Tungkai Dan Kekuatan Otot Perut Terhadap Ketepatan Menendang Bola Pemain Tim Sepakbola Putra SMA Negeri Rengel Kabupaten Tuban. Jurnal. Kediiri : FKIP Universitas Nusantara PGRI Kediri.

[5] Ismaryati. 2006. Tes Pengukuran Olahraga. Surakarta: Sebelas Maret University Press.

[6] Luxbacer, Joseph A. 2011. Sepak bola (Edisi Kedua). Jakarta : Raja Grafindo Persada

[7] Robert, Konger. 2007. Latihan Dasar Sepakbola Remaja. Klaten : PT Saka Mitra Kompetisi

[8] Soniawan, V. Metode Bermain Berpengaruh Terhadap Kemampuan Long Passing Sepakbola.

[9] Sukadiyanto, 2011. Pengantar Teori Dan Metodologi Melatih Fisik. Bandung : Lubuk Agung.

[10] Syukur, A., \& Soniawan, V. (2015). THE EFFECTS OF TRAINING METHODS AND ACHIEVEMENT MOTIVATION TOWARD OF FOOTBALL PASSING SKILLS. JIPES-JOURNAL OF INDONESIAN PHYSICAL EDUCATION AND SPORT, 1(2), 73-84. 